\title{
THE EMPIRICAL ANALIYSIS OF THE PURCHASING POWER PARITY IN ROMANIA
}

\author{
Ecaterina TOMOIAGĂ $\breve{a *}^{\mathrm{a}}$ \\ a) Babes-Bolyai University, Faculty of Economics and Business Administration, \\ Cluj-Napoca, Romania
}

Please cite this article as:

Article History:

Tomoiagă, E., 2019. The empirical analysis of the Received: 10 August 2019 purchasing power parity in Romania. Review of Accepted: 24 September 2019 Economic Studies and Research Virgil Madgearu, 12(2), pp.145-154.

doi: 10.24193/RVM.2019.12.45.

Abstract: In this paper we test the validity of purchasing power parity for
Romania in relation with the main trading partner EU19. To the best of our
knowledge, there is no any other similar study in the literature so far. The utility
of the study comes from the possibility of offering trade policy recommendation
for Romania. The data used in the paper covers the period 2005 (January) - 2019
(March). For estimation, we employ vector error correction model and we reach to
the conclusion that the theory is validated in the short run. Key words: purchasing power parity; exchange rate; vector error correction; consumer price index

JEL Classification: $C_{22}$; F31

(C) 2019 Alma Mater Publishing House. All rights reserved.

* Corresponding author. E-mail address: tomoiagaecaterina@yahoo.com. 


\section{References:}

1. Alba, J.D. and Papell, D.H., 2007. Purchasing power parity and country characteristics: Evidence from panel data tests. Journal of Development Economics, 83, pp.240-251. https://doi.org/10.1016/j. jdeveco.2005.09.006.

2. Eurostat, 2019. [online] Available at: <https://ec.europa.eu/ eurostat/data/database > [Accessed 6 May 2019].

3. He, H., Ranjbar, O. and Chang, T., 2013. Purchasing power parity in transition countries: Old wine with new bottle. Japan and the World Economy, 28(C), pp.24-32. doi: 10.1016/j.japwor.2013.06.002.

4. Jiang, C., Jian, N., Liu, T.Y. and Su, C.W., 2016. Purchasing Power Parity and Real Exchange Rate. International Review of Economics and Finance, 44(C), pp.349-358. doi: 10.1016/j.iref.2016.02.006.

5. Kirchgässner, G.W., 2007. Introduction to Modern Time Series Analysis. Berlin: Springer.

6. Melvin, M. and Norrbin, S.C., 2012. International Money and Finance. Academic Press.

7. Mishkin, F., 2015. Macroeconomics. Pearson Education Limited.

8. Postelnicu, C., 2011. Economie internațională. Cluj-Napoca: Risoprint.

9. Taylor, M.P. and McMahon, P.C., 1988. Long-run Purchasing Power Parity in the 1920s. European economic Review, 32(1), pp.179-197. https://doi.org/10.1016/0014-2921(88)90041-4.

10. Wooldridge, J.M., 2002. Econometric Analysis of Cross Section and Panel Data. London: The MIT Press. 